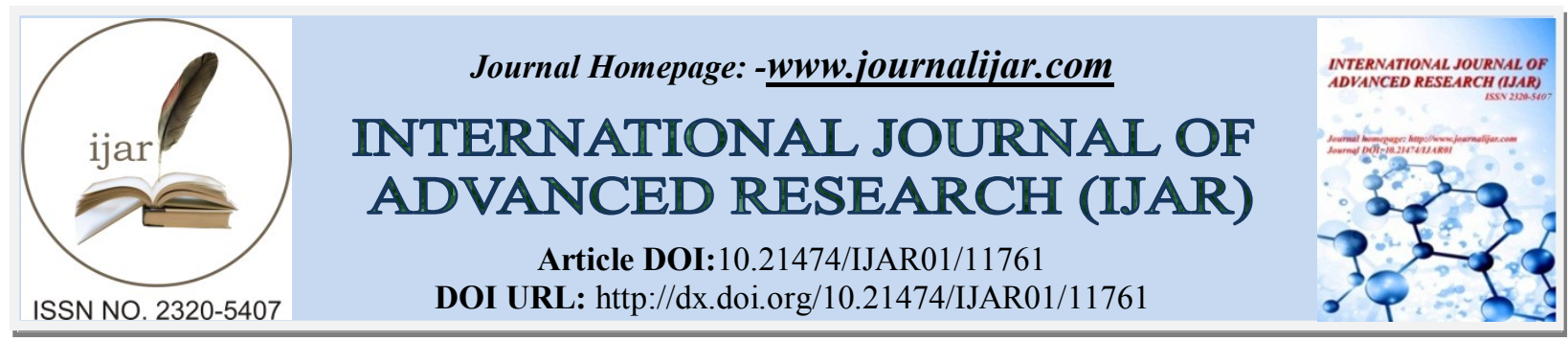

RESEARCH ARTICLE

\title{
IMPACT OF SUSTAINED DEFFICIT IRRIGATION AND FOLIAR SPRAY OF ASCORBIC ACID ON PRODUCTIVITY AND PEEL DISORDERS OF WONDERFUL POMEGRANATE TREES
}

\author{
Amro S.M. Salama, Osama H.M. El Gammal and Amin M. G. E. Shaddad
}

Plant Production Department, Desert Research Center, Cairo, Egypt.

\section{Manuscript Info}

(...........................

Manuscript History

Received: 20 July 2020

Final Accepted: 24 August 2020

Published: September 2020

Key words:-

Wonderful Pomegranate Tree, Sustained Deficit Irrigation, Ascorbic Acid, Yield, Fruit Quality, Fruits Disorders, Water Used Efficiency

\begin{abstract}
The investigation was carried out during 2017and 2018 seasons on Wonderful pomegranate trees grown at private orchard located on "Cairo-Alexandria Desert" road about $50 \mathrm{Km}$ from Cairo, Egypt. Trees planted at $3 \times 5$ meters apart in sandy soil and watered from wells using drip irrigation system. The trial was a factorial experiment, hence sustained deficit irrigation $100 \%, 80 \%$ and $60 \%$ from crop evapotranspiration (ETc) throughout season, the occupied main plot, whereas foliar sprays of ascorbic acid treatments at $0,500,750$ and $1000 \mathrm{ppm} /$ tree located in the subplots were carried out two times, the first foliar spray was done at full bloom and the second one was performed four weeks later. The results showed that leaf characteristics (leaf area and total chlorophyll), number of fruits per tree, yield and fruit quality traits (weigh, length, diameter, weight of fruit grains, flesh percentage, weight of 100 grains and juice volume) recorded the highest values with higher both irrigation level and sprays of ascorbic acid treatments. On the contrary fruits cracked percentage and fruits sunburned percentage, peel thickness, total sugar, TSS, TSS/acidity, ascorbic acid and water used efficiency showed an adverse correlation with irrigation level. Also, spraying by ascorbic acid is reducing number of fruit cracked, number of sunburned fruits and acidity. On other hand, peel thickness, total sugar, TSS, TSS/acidity and ascorbic acid concentration were increasing. Therefore, sustained deficit irrigation is considered to be an effective strategy for arid and semi-arid regions, moreover ascorbic acid may be used to prevent or mitigate oxidative damage caused by sustained deficit irrigation.
\end{abstract}

Copy Right, IJAR, 2020,. All rights reserved.

\section{Introduction:-}

Pomegranate (Punica granatum L.) is belonging to the family Punicaceae and it is one of the oldest known edible fruit. It is considered as an important fruit crop of arid and semi-arid regions. It is recommended for a resource limited farmers. Wonderful pomegranate cultivar is considered one of the most important pomegranate cultivars grown successfully on new reclaimed soils.

Water scarcity is become the one of the main factors limiting agricultural development in Egypt. And agriculture activity will suffer from water shortage currently and in the future irrigation. In addition, irrigation water is limited in most new reclaimed regions. Water scarcity has become a challenge for agricultural production. In this case, 
deficit irrigation is an ideal water saving technique when applied on many fruit orchards. Deficit irrigation has been widely investigated as a valuable strategy under water scarcity (Pereira et al., 2002), reducing agricultural water use (Fereres and Soriano, 2007), for dry region (English, 1990 and Fereres et al., 2003). Deficit irrigation mean the water is applied at rate less than the need of crop evapotranspiration (ETc). The adoption of deficit irrigation by farmers is one of the options that can help to save irrigation water under desert conditions. In irrigated fruit trees, deficit irrigation strategy has been proposed to save water without major effects on yield (Chalmers et al., 1981). Deficit irrigation caused a significant decrease in crop yield compared to full irrigation (Tavousi et al., 2015). Intrigliolo et al. (2012) showed that deficit irrigated treatments allowed increasing water use efficiency. Ghanbarpour et al. (2018) indicated that fruit cracking in the pomegranate cultivar dependent on irrigation. Fruit cracking is a serious problem in pomegranate orchard as it causes about $50 \%$ of fruit marketing value (El-Masry, 1995). Vegetative growth and fruits quality were significantly affected by levels of soil moisture of field capacity (Abdel-Sattar and Mohamed, 2017). Water deficit stress induces numerous biochemical and physiological responses in plants (Pattangual and Madore, 1999). Zahedi and Moghadam (2011) reported that antioxidant enzymes activity was increased when plants were exposed to water deficit. Under conditions of water deficit, reactive oxygen species (ROS), such as superoxide anion radicals, hydrogen peroxide and hydroxyl radicals, are generated (Zhu, 2000). Plant cells contain an array of protection mechanisms and repair systems that can minimize the occurrence of oxidative damage caused by reactive oxygen species (Abdel Latef, 2010). To prevent or mitigate oxidative damage from ROS, plant cells possess a enzymatic antioxidant system that includes tocopherols and ascorbic acid.

Antioxidants such as ascorbic acids are safe to human and environment (Elade, 1992). It has also been reported that application of exogenous ascorbic can reduce oxidative stresses (Shalata and Neumann, 2001). It is considered as an antioxidant and association with other components of the antioxidant system. It protects plants against oxidative damage (Smirnoff, 1996). Ascorbic has been shown to play multiple roles in plant growth, such as in cell division, cell wall expansion and other developmental processes (Lee and Kader, 2000 \&Pignocchi and Foyer, 2003). Moreover, ascorbic acid functions as enzymatic cofactor, and it plays important roles in many physiological processes, including photosynthesis, photo-protection, stress resistance, biosynthesis of hormones and cell wall constituents (Davey et al., 2000 \& Conklin and Barth, 2004). Ascorbic acid has auxinic action. It has a synergistic effect on improving growth, flowering, yield and fruit quality of fruit crops (Barth et al., 2006). Abd-El-Rhman et al. (2017) reported that foliar spray ascorbic acid enhanced yield and fruit quality of Manfaloty pomegranate trees. Atef (2018) pointed out that foliar spray ascorbic acid improved growth, yield fruit quality of Wonderful pomegranate trees.

The aim of this study is to investigate the effect of foliar ascorbic acid under sustained deficit irrigation on vegetative growth, yield and fruit quality as well as water used efficiency of Wonderful pomegranate trees.

\section{Material and Methods:-}

This investigation was carried out during two successive seasons 2017 and 2018 at orchard located on "CairoAlexandria desert" road about $50 \mathrm{~km}$ from Cairo (latitude 30 $0^{\circ} 2.92^{\prime \prime} \mathrm{N}$, longitude $30^{\circ} 40^{\prime} 31.75^{\prime \prime} \mathrm{E}$ at an elevation of $200 \mathrm{~m}$ above sea level), Egypt. Wonderful pomegranate trees (Punica granatum L.) aged 7 years old grown in sandy soil, and spaced 3 x 5 m apart (280 trees / fed) under drip irrigation system from well. Physical and chemical analysis of the experimental soil shown in Table 1, meanwhile the chemical analysis of used water from irrigation is recorded in (Table 2).

This experiment was considered a Factorial design, the sustained deficit irrigation (SDI) $(60 \%, 80 \%$ and $100 \%$ of ETc) being the first factor and ascorbic acid (AsA) foliar sprays (0, 500, 750 and $1000 \mathrm{ppm})$ the second factor, with three replicates for each treatment and each replicate was represented by two plants.

Table 1:-Analysis of experimental soil in 2017 and 2018 seasons.

I - Physical analysis.

\begin{tabular}{|c|c|c|c|c|c|c|c|c|c|}
\hline Soil & \multicolumn{4}{|c|}{ Particle size distribution } & \multirow{2}{*}{$\begin{array}{c}\text { Texture } \\
\text { Class }\end{array}$} & \multirow{2}{*}{$\begin{array}{c}\text { Bulk } \\
\text { Density } \\
(\mathrm{g} / \mathrm{cm})\end{array}$} & \multirow{2}{*}{$\begin{array}{c}\text { Organic } \\
\text { matter } \\
\%\end{array}$} & \multicolumn{2}{|c|}{ Moisture content (\%) } \\
\hline $\begin{array}{l}\text { Depth } \\
(\mathrm{cm})\end{array}$ & $\begin{array}{c}\text { Coarse } \\
\text { sand }\end{array}$ & $\begin{array}{l}\text { Fine } \\
\text { sandy }\end{array}$ & Silt & Clay & & & & $\begin{array}{c}\text { Field } \\
\text { Capacity }\end{array}$ & $\begin{array}{l}\text { Wilting } \\
\text { Point }\end{array}$ \\
\hline $0-30$ & 0.00 & 97.50 & 1.50 & 1.00 & Sand & 1.52 & 0.20 & 9.21 & 4.44 \\
\hline $30-60$ & 0.00 & 98.00 & 1.40 & 0.60 & Sand & 1.56 & 0.19 & 8.88 & 4.49 \\
\hline
\end{tabular}


II- chemical analysis.

\begin{tabular}{|c|c|c|c|c|c|c|c|c|c|c|c|}
\hline \multirow{2}{*}{$\begin{array}{c}\text { Soil } \\
\text { Depth } \\
\text { cm }\end{array}$} & \multirow{2}{*}{$\mathrm{CaCO}_{3}$} & \multirow{2}{*}{$\begin{array}{l}\mathrm{pH} \\
\text { Soil } \\
\text { past }\end{array}$} & \multirow{2}{*}{$\begin{array}{c}\text { E.Ce } \\
\left(\mathrm{dSm}^{-1}\right)\end{array}$} & \multicolumn{4}{|c|}{ Soluble cations (meq/l) } & \multicolumn{4}{|c|}{ soluble anions (meq/l) } \\
\hline & & & & $\mathrm{Ca}^{++}$ & $\mathrm{K}^{+}$ & $\mathrm{Na}^{+}$ & $\mathrm{Mg}^{++}$ & $\mathrm{Cl}^{-}$ & $\mathrm{SO}_{4}$ & $\mathrm{HCO}_{3}^{-}$ & $\mathrm{CO}_{3}=$ \\
\hline $0-30$ & 4.1 & 7.1 & 1.8 & 3.1 & 1.5 & 11 & 1.8 & 9.5 & 5 & 1.1 & - \\
\hline $30-60$ & 4.2 & 7.1 & 1.4 & 2.8 & 1.4 & 10.2 & 1.3 & 8.5 & 4.5 & 1.2 & - \\
\hline
\end{tabular}

Table 2:- Chemical analysis of water used for irrigation in 2017 and 2018 seasons.

\begin{tabular}{|c|c|c|c|c|c|c|c|c|c|c|}
\hline \multirow[t]{2}{*}{$\mathrm{pH}$} & \multirow{2}{*}{$\begin{array}{l}\text { E.C. } \\
\text { dSm }^{-1}\end{array}$} & \multirow{2}{*}{$\begin{array}{c}\text { O.M } \\
\%\end{array}$} & \multicolumn{4}{|c|}{ Soluble cations (meq/l) } & \multicolumn{4}{|c|}{ soluble anions (meq/l) } \\
\hline & & & $\mathrm{Ca}^{++}$ & $\mathrm{Mg}^{++}$ & $\mathrm{Na}^{+}$ & $\mathrm{K}^{+}$ & $\mathrm{CO}_{3}{ }^{=}$ & $\mathrm{HCO}_{3}$ & $\mathrm{Cl}^{-}$ & $\mathrm{SO}_{4}{ }^{\prime}$ \\
\hline 7.00 & 0.6 & 0.8 & 1.8 & 1.2 & 0.6 & 0.9 & 0 & 1.8 & 2.6 & 0.1 \\
\hline
\end{tabular}

Irrigation treatments were applied from $1^{\text {st }}$ February and continued until $20^{\text {th }}$ September, then stopped until harvest date $5^{\text {th }}$ October, after that completed irrigation until the end of October for both seasons, and was programmed twice per week during the afternoon based on calculation crop evapotranspiration (ETc) which was done by using the following method:

Water requirement for irrigation was calculated as potential crop evapotranspiration (ETc), based on climatic data obtained from Central Lab. for Agricultral Climate, using CROPWAT computer program. The reference evapotranspiration ETo, was calculated by Penman-Monteith equation (Allen et al., 1998). Then the crop evapotranspiration (ETc) was calculated by using the following formula according to Doorembos and Pruitt (1977).

Where:

$$
\mathrm{ETc}=\mathrm{ETo} \times \mathrm{Kc} \quad(\mathrm{mm} . \text { day- } 1)
$$

$\mathrm{ETo}=$ Reference crop evapotranspiration $\left(\mathrm{mm} \cdot \mathrm{day}^{-1}\right), \mathrm{Kc}=\mathrm{Crop}$ coefficient according to (Intrigliolo et al., 2011).

Then irrigation requirements (IR) were calculated by using the following equation

$\mathrm{IR}=\mathrm{ETc} \times \mathrm{Kr} \times \mathrm{Pw} \times \mathrm{Ea} \times \mathrm{Ec} \quad(2)$

Where: $\mathrm{Kr}=$ Reduction coefficient, $\mathrm{Pw}$ : Rate wit soil $=0.40$ under drip irrigation system, Ea: Irrigation application

$=0.85$, Ec: Conveyance efficiency $=0.90$

$\mathrm{Kr}=2 \mathrm{C} / 100$

$\mathrm{C}=3 / 4 \times \pi \times \mathrm{a} \times \mathrm{b}^{2}(4)$

When (a) is of canopy height (m), and (b) is half of canopy spread (m) according to Westwood (1993)

The four treatments regarding ascorbic acid spraying were: control tap water, , ascorbic acid as foliar sprays at 500 ppm, ascorbic acid as foliar sprays at $750 \mathrm{ppm}$, ascorbic acid as foliar sprays at $1000 \mathrm{ppm}$. Were carried out two times, the first foliar spray was done at full bloom and the second one was performed four weeks later, in both seasons. Tween- 20 was added at $0.1 \%$ as a surfactant to spray solution including the control "tap water". Spraying was carried out using compression sprayers (5L solution per tree) at the previously mentioned dates. This study is considered a factorial experiment hence a split plot is devoted to the sustained deficit Irrigation as main plot whereas ascorbic acid foliar occupied sub-plot. The element of each factor was replicated three times.

Seventy two healthy trees, nearly uniform in shape, size, and productivity received the same horticulture practices were subjected to the tested sustained deficit irrigation and ascorbic acid treatments and evaluated through the following determinations.

\section{Leaf characteristics}

The area of leaves was determined by using portable area planimeter Mod Li3100 Ali (Li-Cor) while Leaf total chlorophyll content was determined by Minolta chlorophyll meter SPAD-502.

\section{Number of fruits/tree and yield $\mathrm{kg} / \mathrm{tree}$}

At harvest time, the number of fruits per each treated tree was counted and reported then yield $(\mathrm{kg})$ per tree was weighed and recorded

\section{Cracked and sunburned fruits}

Number of cracked and sunburned fruits per tree was counted and recorded. 


\section{Fruit physical and chemical properties}

Ten fruits were taken at harvest from each treated tree for determination of the following physical and chemical properties. Fruit weight $(\mathrm{g})$, fruit length $(\mathrm{cm})$, fruit diameter $(\mathrm{cm})$, weight of fruit grains $(\mathrm{g})$, flesh $(\%)$, weight of 100 grains (g), juice volume $\left(\mathrm{cm}^{3}\right)$ per fruit, peel thickness. Furthermore, total sugar $(\%)$, total soluble solids (T.S.S.) was determined by Hand refractometer, total acidity in fruit juice (expressed as citric acid per $100 \mathrm{ml}$ juice), TSS/ Acid ratio and ascorbic acid (mg ascorbic acid/100 ml juice) according to A.O.A.C. (1995).

Water use efficiency $\left(\mathrm{kg} / \mathrm{m}^{3}\right)$

Water use efficiency (WUE) was defined as kilograms of fruits per one cubic meter of water consumed. It was calculated during two seasons, according to (Yaron et al., 1973) as follow:

$$
W U E=\frac{Y}{c u} \quad\left(\mathrm{Kg} \cdot \mathrm{m}^{-3} \cdot \text { tree }^{-1}\right)
$$

Where: WUE $=$ Water use efficiency $\left(\mathrm{kg} \cdot \mathrm{m}^{-3} \cdot \operatorname{tree}^{-1}\right), \mathrm{Y}=$ Seasonal yield, $\left(\mathrm{kg} \cdot \mathrm{tree}^{-1}\right), \mathrm{CU}=$ Water consumptive use, $\left(\mathrm{m}^{3} \cdot\right.$ tree $\left.^{-1}\right)$

\section{Statistical analysis}

The obtained data in 2017 and 2018 seasons were statistically analyzed by MSTAT-C soft-ware and means were differentiated using Rang test at the 0.05 level (Duncan, 1955).

\section{Results and Discussion:- Leaf characteristics}

Leaf area $\left(\mathrm{cm}^{2}\right)$

Table, 3 illustrate that significant differences were noticed between the tested irrigation levels. However, under sustained deficit irrigation treatments level $100 \%$ irrigation resulted the highest increment in the leaf area value followed descending by $80 \%$ and $60 \%$ irrigation treatment in both two seasons, respectively.

Moreover, spraying treatments of ascorbic acid increased leaf area as compared with the control in both seasons of study; the highest leaf area was recorded with ascorbic acid foliar spray at $1000 \mathrm{ppm}$ treatment followed ascorbic acid at $750 \mathrm{ppm}$ treatment and ascorbic acid at $500 \mathrm{ppm}$ and control (tap water), respectively.

However, the interaction between the two tested factors showed that irrigation at $100 \%$ support with ascorbic acid foliar spray at $1000 \mathrm{ppm}$ recorded the highest value on the leaf area value $\left(5.56\right.$ and $5.45 \mathrm{~cm}^{2}$ ) followed descending by ascorbic acid foliar spray at $750 \mathrm{ppm}\left(5.28\right.$ and $\left.5.05 \mathrm{~cm}^{2}\right)$ ascorbic acid foliar spray at $500 \mathrm{ppm}$ treatment $(4.76$ and $\left.4.58 \mathrm{~cm}^{2}\right)$ and control (tap water) $\left(4.23\right.$ and $\left.3.93 \mathrm{~cm}^{2}\right)$ in both two seasons, respectively. The same trend noticed with other levels irrigation $80 \%$ or $60 \%$. In the other side, irrigation treatment at $100 \%$ combined with spraying ascorbic acid at $1000 \mathrm{ppm}$ proved to be the best interaction in this regard.

\section{Leaf total chlorophyll content}

Table, 3 shows that $100 \%$ level of irrigation gave the highest value of total chlorophyll followed by $80 \%$ in descending order. Meanwhile, the lowest total chlorophyll value was recorded with $60 \%$ irrigation in both seasons.

In addition, the highest total chlorophyll value was recorded with $1000 \mathrm{ppm}$ ascorbic acid while control treatment recorded the lowest values in this respect. Moreover, no significant differences were noticed between ascorbic acid treatments at 750 and $500 \mathrm{ppm}$.

Irrigation levels with spray treatments showed that irrigation at $80 \%$ with ascorbic acid foliar spray at $1000 \mathrm{ppm}$ gave high value in total chlorophyll (57.36, and 58.16) followed descending by ascorbic acid foliar spray at $750 \mathrm{ppm}$ (54.47, and 55.20) ascorbic acid foliar spray at $500 \mathrm{ppm}$ treatment (53.33and 52.93) and control (tap water) (47.66 and 47.67 ) in both two seasons, respectively in this regard. The same trend noticed with other levels irrigation $100 \%$ or $60 \%$.

The combined effects of irrigation levels with spray treatments showed that $100 \%$ irrigation level with ascorbic acid at $1000 \mathrm{ppm}$ was the most effective treatment in increasing total chlorophyll, finally irrigation level at $60 \%$ combined with control treatment resulted in less effective in total chlorophyll. 
Table 3:- Effect of sustained deficit irrigation and foliar application of ascorbic acid on leaf characteristics of Wonderful pomegranate trees ( $2017 \& 2018$ seasons).

\begin{tabular}{|l|l|l|l|l|l|l|l|l|l|l|}
\hline \multicolumn{10}{|l|}{} \\
\hline \\
\hline
\end{tabular}

Means followed by the same letter (s) within each row, column or interaction are not significantly different at $5 \%$ level.

The obtained results regarding the effect of sustained deficit irrigation on leaf characters go in line with the findings of Khattab et al. (2011) and Haneef et al. (2014) on pomegranate trees. They indicated that high irrigation level was increased leaf area. Abo-Taleb et al. (1998) mentioned that chlorophyll (a \& b) of pomegranate trees decreased under severe water stress.

The enhancement effect of ascorbic acid on leaf characters may be attributed that ascorbic acid has positive action in catching all free radicals produced during plant metabolism (Alscher et al., 1997). Moreover, ascorbic acid has an auxinic action and synergistic effect on tree growth (Ragab, 2002). Ascorbic acid may serve as a potential growth regulator to enhance stress resistance in several species (Shalata and Peter, 2001 and Khan, 2006). Foliar application of ascorbic acid increased in photosynthesis (Tarraf et al., 1999). The obtained results regarding the effect of ascorbic acid on leaf characteristics go in line with the findings of El-Sayed et al. (2014) mentioned that ascorbic acid treatments enhanced leaf area and total chlorophyll of Manzanillo olive trees. Atef (2018) showed that foliar sprays with ascorbic acid enhanced growth parameters of "Wonderful" pomegranate trees.

\section{No. of fruits/tree and yield $\mathrm{kg} / \mathrm{tree}$}

No. of fruits/ tree

Table, 4 indicates that irrigation level at $100 \%$ recorded the highest number of fruits per tree followed irrigation level at $80 \%$ and irrigation level at $60 \%$, respectively in both seasons.

Furthermore ascorbic acid $1000 \mathrm{ppm}$ treatment gave the highest increment in number of fruits per tree followed by ascorbic acid at $750 \mathrm{ppm}$, ascorbic acid at $500 \mathrm{ppm}$ and control treatment.

Meanwhile, the interaction between irrigation and spraying treatments revealed that the highest number of fruits per tree value was recorded with irrigation level at $100 \%$ combined with spraying ascorbic acid at $1000 \mathrm{ppm}$. On the contrary, the combination between $60 \%$ irrigation level and tab water foliar spray gave the least positive effect on increment on the number of fruits per tree. Irrigation level at $60 \%$ with spray treatments ascorbic acid at $1000 \mathrm{ppm}$ proved to be effective interaction in increasing number of fruits per tree (69.83and 67.83) followed descending by ascorbic acid foliar spray at $750 \mathrm{ppm}$ (65.0 and 57.66) ascorbic acid foliar spray at $500 \mathrm{ppm}$ treatment (57.5 and 52.16) and control (tap water) (52.0 and 46.33) in both two seasons, respectively in this respect. The same trend noticed with other levels irrigation $100 \%$ or $80 \%$. 
Table 4:- Effect of sustained deficit irrigation and foliar application of ascorbic acid on No. of fruits/tree and Yield $(\mathrm{kg}) /$ tree of Wonderful pomegranate trees $(2017$ \& 2018 seasons).

\begin{tabular}{|l|l|l|l|l|l|l|l|l|l|}
\hline \multicolumn{10}{|l|}{} \\
\hline \multicolumn{8}{|l|}{ No. of fruits/tree } \\
\hline \multicolumn{9}{|l|}{2017} \\
\hline
\end{tabular}

Means followed by the same letter (s) within each row, column or interaction are not significantly different at $5 \%$ level.

\section{Yield (Kg) / tree}

It is clear from Table, 4 that significant differences on tree yield were resulted negatively by reducing irrigation rate. However, irrigation level at $100 \%$ produced the highest yield as compared with those given by a reduction $60 \%$ in both seasons. On the other hand, a reduction $80 \%$ gave an intermediate effect in this respect in both seasons.

Furthermore, Table, 4 shows that spraying ascorbic acid at $1000 \mathrm{ppm}$ gave the highest increment in yield (24 and $25 \mathrm{~kg} /$ tree) followed by ascorbic acid at $750 \mathrm{ppm}(21.67$ and $22.32 \mathrm{~kg} /$ tree $)$, ascorbic acid at $500 \mathrm{ppm}$ (20 and 19 $\mathrm{kg} /$ tree) and control treatment (16.33 and $16.0 \mathrm{~kg} /$ tree) respectively in the two seasons.

In addition, irrigation at $100 \%$ combined with ascorbic acid foliar spray at $1000 \mathrm{ppm}$ proved to be the most effective treatment in improving yield $(\mathrm{kg}) /$ tree $(27.5$, and $28.51 \mathrm{~kg} /$ tree $)$ followed descending by ascorbic acid foliar spray at $750 \mathrm{ppm}(24.67$ and $25.32 \mathrm{~kg} / \mathrm{tree})$ ascorbic acid foliar spray at $500 \mathrm{ppm}$ treatment (22.5 and $21.5 \mathrm{~kg} / \mathrm{tree})$ and control (tap water) $(18.32$ and $18.0 \mathrm{~kg} /$ tree $)$ in both two seasons, respectively in this regard. The same trend noticed with other levels irrigation $80 \%$ or $60 \%$.

The obtained results regarding the effect of sustained deficit irrigation on yield go in line with the findings of Khattab et al. (2011) mentioned that high irrigation level increased yield of pomegranate trees. Abd-Ella (2011) found that high irrigation level enhanced yield of pomegranate trees. Abdel-Sattar and Mohamed (2017) pointed that the treatment of $100 \%$ field capacity gave the highest yield value of pomegranate trees. Haneef et al. (2014) showed that irrigation level $(100 \%)$ registered maximum number of fruits and yield of pomegranate trees.

The enhancement effect of ascorbic acid on yield may be attributed that ascorbic acid increased leaf chlorophyll content (Azzedine, et al., 2011). This led to an enhancement of photosynthesis process (Tarraf et al., 1999).which led to more carbohydrate production and that reflected in higher yield. The obtained results regarding the effect of ascorbic acid on yield go in line with the findings of Fayed (2010) on pomegranate treesand Abd-El-Rhman et al. (2017) on "Manfaloty" pomegranate trees and Atef (2018) on "Wonderful" pomegranate trees.

\section{Fruits cracked and fruit sunburned percentages}

Fruit cracked percentage.

Table, 5 illustrates that under sustained deficit irrigation, reduction irrigation at $60 \%$ recorded the lowest fruit cracked percentage compared with those given full irrigation level in both seasons. On the other hand, reduction $80 \%$ irrigation level of gave an intermediate effect in this respect. 
Moreover, ascorbic acid treatments reduced fruit cracked percentage as compared with the control in both seasons. $1000 \mathrm{ppm}$ of ascorbic acid treatment recorded the lowest values of fruit cracked percentage tree against for the control treatment in two seasons.

The interaction between the two tested factors indicated that sustained deficit irrigation combined with ascorbic acid spraying treatments succeeded in reducing fruit cracked percentage in both seasons. Shortly, reduction of irrigation $60 \%$ treatment combined with $1000 \mathrm{ppm}$ ascorbic acid treatment reduced of fruit cracked percentage in this concern.

AS while, $1000 \mathrm{ppm}$ of ascorbic acid treatment with any of irrigation levels $(100 \%, 80 \%$ and $60 \%)$ recorded the lowest values of fruit cracked percentage against for the control treatment control with any of irrigation levels $(100 \%, 80 \%$ and $60 \%)$ in two seasons.

Table 5:- Effect of sustained deficit irrigation and foliar application of ascorbic acid on fruits cracked percentage and fruits sunburned percentage of Wonderful pomegranate trees ( 2017 \& 2018 seasons).

\begin{tabular}{|c|c|c|c|c|c|c|c|c|c|c|}
\hline & \multicolumn{10}{|c|}{ Fruits cracked percentage } \\
\hline & \multicolumn{5}{|l|}{2017} & \multicolumn{5}{|l|}{2018} \\
\hline & \multicolumn{5}{|c|}{ Ascorbic acid } & \multicolumn{5}{|c|}{ Ascorbic acid } \\
\hline Treatments & $0 \mathrm{ppm}$ & $\begin{array}{l}500 \\
\mathrm{ppm}\end{array}$ & $\begin{array}{l}750 \\
\text { ppm }\end{array}$ & $\begin{array}{l}1000 \\
\mathrm{ppm}\end{array}$ & Mean & $0 \mathrm{ppm}$ & $\begin{array}{l}500 \\
\text { ppm }\end{array}$ & $\begin{array}{l}750 \\
\text { ppm }\end{array}$ & $\begin{array}{l}1000 \\
\text { ppm }\end{array}$ & Mean \\
\hline Irrigation $100 \%$ & $34.73 \mathrm{a}$ & $24.82 \mathrm{~d}$ & $19.23 \mathrm{~g}$ & $14.85 \mathrm{j}$ & $23.41 \mathrm{~A}$ & $32.42 \mathrm{a}$ & $27.10 \mathrm{~d}$ & $21.36 \mathrm{~g}$ & $12.89 \mathrm{j}$ & $23.45 \mathrm{~A}$ \\
\hline Irrigation $80 \%$ & $33.33 \mathrm{~b}$ & $23.33 \mathrm{e}$ & $17.63 \mathrm{i}$ & $13.15 \mathrm{k}$ & $21.86 \mathrm{~B}$ & $31.02 \mathrm{~b}$ & $25.60 \mathrm{e}$ & $19.76 \mathrm{~h}$ & $11.19 \mathrm{k}$ & $21.89 \mathrm{~B}$ \\
\hline Irrigation $60 \%$ & $31.93 \mathrm{c}$ & $21.82 \mathrm{f}$ & $16.03 \mathrm{i}$ & 11.451 & $20.31 \mathrm{C}$ & $29.62 \mathrm{c}$ & $24.10 \mathrm{f}$ & $18.16 \mathrm{i}$ & 9.491 & $20.35 \mathrm{C}$ \\
\hline \multirow[t]{4}{*}{ Mean } & $33.33 \mathrm{~A}$ & $23.32 \mathrm{~B}$ & $17.63 \mathrm{C}$ & $13.15 \mathrm{D}$ & & $31.20 \mathrm{~A}$ & $25.60 \mathrm{~B}$ & $19.76 \mathrm{C}$ & 11.19D & \\
\hline & \multicolumn{10}{|c|}{ Fruit sunburned percentage } \\
\hline & \multicolumn{5}{|l|}{2017} & \multicolumn{5}{|l|}{2018} \\
\hline & \multicolumn{5}{|c|}{ Ascorbic acid } & \multicolumn{5}{|c|}{ Ascorbic acid } \\
\hline Treatments & $0 \mathrm{ppm}$ & $\begin{array}{l}500 \\
\text { ppm }\end{array}$ & \begin{tabular}{|l|}
750 \\
ppm
\end{tabular} & $\begin{array}{l}1000 \\
\text { ppm }\end{array}$ & Mean & $\begin{array}{l}0 \\
\mathrm{ppm}\end{array}$ & $\begin{array}{l}500 \\
\text { ppm }\end{array}$ & $\begin{array}{l}750 \\
\text { ppm }\end{array}$ & $\begin{array}{l}1000 \\
\text { ppm }\end{array}$ & Mean \\
\hline Irrigation $100 \%$ & $16.20 \mathrm{a}$ & $13.70 \mathrm{c}$ & $11.38 \mathrm{de}$ & $9.40 \mathrm{f}$ & $12.67 \mathrm{~A}$ & $15.87 \mathrm{a}$ & $14.89 \mathrm{~b}$ & $13.13 \mathrm{c}$ & $11.50 \mathrm{~d}$ & $13.85 \mathrm{~A}$ \\
\hline Irrigation $80 \%$ & $14.80 \mathrm{~b}$ & $12.20 \mathrm{~d}$ & $9.78 \mathrm{f}$ & $7.70 \mathrm{~g}$ & $11.12 \mathrm{~B}$ & $14.47 \mathrm{~b}$ & $13.39 \mathrm{c}$ & $11.53 \mathrm{~d}$ & $9.80 \mathrm{e}$ & $12.30 \mathrm{~B}$ \\
\hline Irrigation $60 \%$ & $13.40 \mathrm{c}$ & $10.70 \mathrm{e}$ & $8.18 \mathrm{~g}$ & $6.01 \mathrm{~h}$ & $9.57 \mathrm{C}$ & $13.07 \mathrm{c}$ & $11.89 \mathrm{~d}$ & $9.93 \mathrm{~d}$ & $8.10 \mathrm{f}$ & $10.75 \mathrm{C}$ \\
\hline Mean & $14.80 \mathrm{~A}$ & $12.20 \mathrm{~B}$ & $9.78 \mathrm{C}$ & $7.70 \mathrm{D}$ & & $14.47 \mathrm{~A}$ & $13.39 \mathrm{~B}$ & $11.53 \mathrm{C}$ & $9.80 \mathrm{D}$ & \\
\hline
\end{tabular}

Means followed by the same letter (s) within each row, column or interaction are not significantly different at $5 \%$ level.

Fruits sunburned percentage.

Table, 5 shows regulated deficit irrigation treatments. Irrigation level at $60 \%$ reduced of fruits sunburned percentage as compared with the irrigation level at $80 \%$ and irrigation level at $100 \%$ treatments in the both seasons of this study.

Moreover, Ascorbic acid treatments scored comparatively lower values of sunburned percentage than did control treatments. In this respect, $1000 \mathrm{ppm}$ ascorbic acid treatment recorded the lowest values of sunburned percentage against for the control treatment in two seasons.

The interaction between the two tested factors showed irrigation level at $60 \%$ combined with ascorbic acid at 1000 ppm high reductive effect on sunburned percentage and surpassed other combinations in reducing sunburned percentage in both seasons.

High level of ascorbic acid at $1000 \mathrm{ppm}$ combined with any of irrigation levels $(100 \%, 80 \%$ and $60 \%)$ reductive effect on sunburned percentage as compared with the control treatment combined with same irrigation levels previously in both seasons of study.

The obtained results regarding the effect of sustained deficit irrigation on cracked and sunburned fruits go in line with the findings of Khattab et al. (2011). They indicated that high irrigation level increased fruit cracking but low 
irrigation level gave the lowest fruit cracking of pomegranate trees. Ghanbarpour et al. (2018) indicated that fruit cracking in the pomegranate cultivar dependent on irrigation. In addition, deficit irrigation caused a significant decrease in crop yield compared to full irrigation of pomegranate trees (Tavousi et al., 2015).

The positive effect of ascorbic acid in reducing cracked and sunburned fruits may be attributed that ascorbic acid has catch all free radicals produced during plant metabolism (Nichloas, 1996). Ascorbic acidincreased IAA content, which stimulates cell division as well as cell enlargement and this in turn in improved plant growth (Hassanein et al., 2009). Ascorbic acid may serve as a potential growth regulator to enhance stress resistance in several species (Khan, 2006). This led to reducing cracked fruit. Furthermore, ascorbic acid reduces sunburn damage in fuji apples (Andrews et al., 1999). The obtained results regarding the effect of ascorbic acid on fruit cracking and sunburned fruits go in line with the findings of Ahmed et al. (1997) showed that ascorbic acid application was controlling the incidence of fruit disorders of apple trees, it was reduced fruit splitting of Manfalouty pomegranate (Ahmed et al., 2014), and Abd-El-Rhman et al., (2017) pointed out that foliar spray ascorbic acid reduced fruit cracked percentage of Manfalouty pomegranate trees.

\section{Fruit physical and chemical properties}

Fruit weight (g)

Data presented in Table, 6 indicated that the highest increment in fruit weight values were recorded with $100 \%$ irrigation followed by reduction irrigation at $80 \%$ and $60 \%$, respectively.

Furthermore, the highest increments fruit weight values were recorded with ascorbic acid at $1000 \mathrm{ppm}$ followed by ascorbic acid at $750 \mathrm{ppm}$ compared to control treatment in both seasons.

The interaction effect of irrigation and spray treatment proved that the highest fruit weight values were scored with irrigation level at $100 \%$ plus ascorbic acid at $1000 \mathrm{ppm}$, while the lowest values were recorded with irrigation level at $60 \%$ with control treatment.

Table 6:- Effect of sustained deficit irrigation and foliar application of ascorbic acid on fruit weight $(\mathrm{g})$ and fruit length $(\mathrm{cm})$ of Wonderful pomegranate trees $(2017 \& 2018$ seasons).

\begin{tabular}{|c|c|c|c|c|c|c|c|c|c|c|}
\hline & \multicolumn{10}{|c|}{ Fruit weight (g) } \\
\hline & \multicolumn{5}{|l|}{2017} & \multicolumn{5}{|l|}{2018} \\
\hline & \multicolumn{5}{|c|}{ Ascorbic acid } & \multicolumn{5}{|c|}{ Ascorbic acid } \\
\hline Treatments & $0 \mathrm{ppm}$ & $\begin{array}{l}500 \\
\mathrm{ppm}\end{array}$ & $\begin{array}{l}750 \\
\text { ppm }\end{array}$ & $\begin{array}{l}1000 \\
\mathrm{ppm}\end{array}$ & Mean & $0 \mathrm{ppm}$ & $\begin{array}{l}500 \\
\mathrm{ppm}\end{array}$ & $\begin{array}{l}750 \\
\mathrm{ppm}\end{array}$ & $\begin{array}{l}1000 \\
\mathrm{ppm}\end{array}$ & Mean \\
\hline Irrigation $100 \%$ & $312.20 \mathrm{~g}$ & $334.87 \mathrm{~d}$ & $346.87 \mathrm{ab}$ & $353.53 \mathrm{a}$ & $336.87 \mathrm{~A}$ & $306.20 \mathrm{e}$ & $328.87 \mathrm{c}$ & $341.87 \mathrm{c}$ & $351.53 a$ & $332.12 \mathrm{~A}$ \\
\hline Irrigation $80 \%$ & $301.00 \mathrm{~h}$ & $323.67 \mathrm{f}$ & $335.67 \mathrm{~cd}$ & $342.33 b c$ & $325.67 \mathrm{~B}$ & $295.00 \mathrm{f}$ & $317.67 \mathrm{~d}$ & $330.66 \mathrm{c}$ & $340.33 b$ & $320.92 \mathrm{~B}$ \\
\hline Irrigation $60 \%$ & $289.80 \mathrm{i}$ & $312.47 \mathrm{~g}$ & $324.47 \mathrm{ef}$ & 331.13de & $314.47 \mathrm{C}$ & $283.80 \mathrm{~g}$ & $306.47 \mathrm{e}$ & $319.47 \mathrm{~d}$ & $329.13 \mathrm{c}$ & $309.72 \mathrm{C}$ \\
\hline \multirow[t]{4}{*}{ Mean } & $301.00 \mathrm{D}$ & $323.67 \mathrm{C}$ & $335.67 \mathrm{~B}$ & $342.33 \mathrm{~A}$ & & 295.00D & $317.67 \mathrm{C}$ & $330.68 \mathrm{~B}$ & $340.33 \mathrm{~A}$ & \\
\hline & \multicolumn{10}{|c|}{ Fruit length $(\mathrm{cm})$} \\
\hline & \multicolumn{5}{|l|}{2017} & \multicolumn{5}{|l|}{2018} \\
\hline & \multicolumn{5}{|c|}{ Ascorbic acid } & \multicolumn{5}{|c|}{ Ascorbic acid } \\
\hline Treatments & $0 \mathrm{ppm}$ & $\begin{array}{l}500 \\
\text { ppm }\end{array}$ & $\begin{array}{l}750 \\
\text { ppm }\end{array}$ & $\begin{array}{l}1000 \\
\mathrm{ppm}\end{array}$ & Mean & $0 \mathrm{ppm}$ & $\begin{array}{l}500 \\
\mathrm{ppm}\end{array}$ & $\begin{array}{l}750 \\
\text { ppm }\end{array}$ & $\begin{array}{l}1000 \\
\mathrm{ppm}\end{array}$ & Mean \\
\hline Irrigation $100 \%$ & $8.40 \mathrm{~d}$ & $8.63 \mathrm{c}$ & $8.77 \mathrm{~b}$ & $8.89 \mathrm{a}$ & $8.67 \mathrm{~A}$ & $8.41 \mathrm{~d}$ & $8.64 \mathrm{c}$ & $8.79 \mathrm{~b}$ & $8.90 \mathrm{a}$ & $8.68 \mathrm{~A}$ \\
\hline Irrigation $80 \%$ & $7.88 \mathrm{~g}$ & $8.11 \mathrm{~g}$ & $8.24 \mathrm{e}$ & $8.37 \mathrm{~d}$ & $8.15 \mathrm{~B}$ & $7.89 \mathrm{~h}$ & $8.12 \mathrm{~g}$ & $8.27 \mathrm{f}$ & $8.38 \mathrm{e}$ & $8.16 \mathrm{~B}$ \\
\hline Irrigation $60 \%$ & $7.36 \mathrm{j}$ & $7.59 \mathrm{i}$ & $7.72 \mathrm{~h}$ & $7.85 \mathrm{~g}$ & $7.63 \mathrm{C}$ & 7.371 & $7.60 \mathrm{k}$ & $7.75 \mathrm{j}$ & $7.86 \mathrm{i}$ & $7.64 \mathrm{C}$ \\
\hline Mean & $7.88 \mathrm{D}$ & $8.11 \mathrm{C}$ & $8.24 \mathrm{~B}$ & $8.38 \mathrm{~A}$ & & $7.89 \mathrm{D}$ & $8.12 \mathrm{C}$ & $8.27 \mathrm{~B}$ & $8.38 \mathrm{~A}$ & \\
\hline
\end{tabular}

Means followed by the same letter (s) within each row, column or interaction are not significantly different at $5 \%$ level.

\section{Fruit length $(\mathrm{cm})$}

Table, 6 demonstrates that increasing irrigation level from $60 \%$ and $80 \%$ to $100 \%$ cause a steady increase in fruit length in both seasons. 
Furthermore, it is clear that $1000 \mathrm{ppm}$ ascorbic acid treatment recorded the highest fruit length followed by $750 \mathrm{ppm}$ ascorbic acid, $500 \mathrm{ppm}$ ascorbic acid and control treatments, respectively.

Moreover, the interaction between irrigation levels and spraying ascorbic acid treatments showed that irrigation level at $100 \%$ supplemented with ascorbic acid at $1000 \mathrm{ppm}$ spraying treatment scored the highest values of fruit length while the lowest value was recorded with the combination of irrigation level at $60 \%$ and control treatment. Other interaction scored in between rather in this respect.

Fruit diameter (cm)

Table, 7 illustrates that $100 \%$ irrigation gave the highest fruit diameter followed discerningly by $80 \%$ irrigation level. Meanwhile, irrigation at $60 \%$ recorded the lowest fruit diameter.

Furthermore, it is evident that the highest fruit diameter was recorded with ascorbic acid at $1000 \mathrm{ppm}$ followed by ascorbic acid at $750 \mathrm{ppm}$ as compared to control treatment.

In addition, irrigation at $100 \%$ combined with ascorbic acid at $1000 \mathrm{ppm}$ spraying treatment proved to be the most effective treatment in improving fruit diameter. On the contrary, reduction irrigation at $60 \%$ of (ETc) combined with spray treatment control gave comparatively the lowest values in this respect.

\section{Weight of fruit grains (g)}

Table, 7 shows that $100 \%$ level of irrigation gave the highest weight of fruit grains followed by descending that irrigation level at $80 \%$. Moreover, reducing that irrigation level at $60 \%$ has recorded the lowest of weight of fruit grains.

Furthermore spraying treatment ascorbic acid at $1000 \mathrm{ppm}$ treatment induced the highest weight of fruit grains followed by ascorbic acid at $750 \mathrm{ppm}$, ascorbic acid at $500 \mathrm{ppm}$ treatments and control treatment in descending order.

In addition, irrigation at $100 \%$ combined with ascorbic acid at $1000 \mathrm{ppm}$ spraying treatment proved to be the most effective treatment in improving weight of fruit grains. On the contrary, $50 \%$ irrigation combined with tab water spray treatment gave comparatively the lowest values in this respect.

Table 7:- Effect of sustained deficit irrigation and foliar application of ascorbic acid on fruit diameter $(\mathrm{cm})$ and weight of fruit grains (g) of Wonderful pomegranate trees ( $2017 \& 2018$ seasons).

\begin{tabular}{|c|c|c|c|c|c|c|c|c|c|c|}
\hline & \multicolumn{10}{|c|}{ Fruit diameter $(\mathrm{cm})$} \\
\hline & \multicolumn{5}{|l|}{2017} & \multicolumn{5}{|l|}{2018} \\
\hline & \multicolumn{5}{|c|}{ Ascorbic acid } & \multicolumn{5}{|c|}{ Ascorbic acid } \\
\hline Treatments & $0 \mathrm{ppm}$ & $\begin{array}{l}500 \\
\text { ppm }\end{array}$ & $\begin{array}{l}750 \\
\mathrm{ppm}\end{array}$ & $\begin{array}{l}1000 \\
\mathrm{ppm}\end{array}$ & Mean & $0 \mathrm{ppm}$ & $\begin{array}{l}500 \\
\mathrm{ppm}\end{array}$ & $\begin{array}{l}750 \\
\text { ppm }\end{array}$ & $\begin{array}{l}1000 \\
\mathrm{ppm}\end{array}$ & Mean \\
\hline Irrigation $100 \%$ & $8.92 \mathrm{f}$ & $9.04 \mathrm{~d}$ & $9.08 \mathrm{c}$ & $9.28 \mathrm{a}$ & $9.08 \mathrm{~A}$ & $8.84 \mathrm{D}$ & $8.98 \mathrm{C}$ & $9.10 \mathrm{~B}$ & $9.27 \mathrm{~A}$ & $9.05 \mathrm{~A}$ \\
\hline Irrigation $80 \%$ & $8.77 \mathrm{~h}$ & $8.89 \mathrm{~g}$ & $8.93 \mathrm{f}$ & $9.13 \mathrm{~b}$ & $8.93 \mathrm{~B}$ & $8.69 \mathrm{~F}$ & $8.83 \mathrm{DE}$ & $8.95 \mathrm{c}$ & $9.12 \mathrm{~B}$ & $8.90 \mathrm{~B}$ \\
\hline Irrigation $60 \%$ & $8.62 \mathrm{j}$ & $8.74 \mathrm{i}$ & $8.78 \mathrm{~h}$ & $8.98 \mathrm{e}$ & $8.78 \mathrm{C}$ & $8.54 \mathrm{G}$ & $8.68 \mathrm{f}$ & $8.80 \mathrm{e}$ & $8.97 \mathrm{C}$ & $8.75 \mathrm{C}$ \\
\hline \multirow[t]{4}{*}{ Mean } & $8.77 \mathrm{D}$ & $8.89 \mathrm{C}$ & $8.93 \mathrm{~B}$ & $9.14 \mathrm{~A}$ & & $8.69 \mathrm{D}$ & $8.83 \mathrm{C}$ & $8.95 \mathrm{~B}$ & $9.12 \mathrm{~A}$ & \\
\hline & \multicolumn{10}{|c|}{ Weight of fruit grains $(\mathrm{g})$} \\
\hline & \multirow{2}{*}{\multicolumn{5}{|c|}{$\begin{array}{l}2017 \\
\text { Ascorbic acid }\end{array}$}} & \multirow{2}{*}{\multicolumn{5}{|c|}{$\begin{array}{l}2018 \\
\text { Ascorbic acid }\end{array}$}} \\
\hline & & & & & & & & & & \\
\hline Treatments & $0 \mathrm{ppm}$ & $\begin{array}{l}500 \\
\mathrm{ppm}\end{array}$ & $\begin{array}{l}750 \\
\mathrm{ppm}\end{array}$ & $\begin{array}{l}1000 \\
\text { ppm }\end{array}$ & Mean & $0 \mathrm{ppm}$ & $\begin{array}{l}500 \\
\text { ppm }\end{array}$ & $\begin{array}{l}750 \\
\mathrm{ppm}\end{array}$ & $\begin{array}{l}1000 \\
\text { ppm }\end{array}$ & Mean \\
\hline Irrigation $100 \%$ & $142.0 \mathrm{~h}$ & $150.67 \mathrm{e}$ & $163.34 \mathrm{c}$ & $177.33 \mathrm{a}$ & $158.33 \mathrm{~A}$ & $141.0 \mathrm{f}$ & $155.0 \mathrm{~d}$ & $164.0 \mathrm{c}$ & $176.67 \mathrm{a}$ & $159.17 \mathrm{~A}$ \\
\hline Irrigation $80 \%$ & $135.0 \mathrm{j}$ & $143.68 \mathrm{~g}$ & $156.33 \mathrm{~d}$ & $170.34 \mathrm{~b}$ & 151.33B & $134.0 \mathrm{~g}$ & $148.0 \mathrm{e}$ & $157.0 \mathrm{~d}$ & $169.67 \mathrm{~b}$ & $152.18 \mathrm{~B}$ \\
\hline Irrigation $60 \%$ & $128.0 \mathrm{k}$ & $136.66 \mathrm{i}$ & $149.34 \mathrm{f}$ & $163.34 \mathrm{c}$ & $144.33 \mathrm{C}$ & $127.0 \mathrm{~h}$ & $141.0 \mathrm{f}$ & $150.0 \mathrm{e}$ & $162.67 \mathrm{c}$ & $145.16 \mathrm{C}$ \\
\hline Mean & $135.0 \mathrm{D}$ & $143.67 \mathrm{C}$ & $156.33 \mathrm{~B}$ & $170.33 \mathrm{~A}$ & & $136.0 \mathrm{D}$ & $148.0 \mathrm{C}$ & $157.0 \mathrm{~B}$ & $169.67 \mathrm{~A}$ & \\
\hline
\end{tabular}

Means followed by the same letter (s) within each row, column or interaction are not significantly different at $5 \%$ level. 


\section{Flesh (\%)}

Data presented in Table, 8 shows that the highest increment in flesh percentage values were recorded with $100 \%$ irrigation followed by irrigation at $80 \%$ and $60 \%$, respectively.

Furthermore, the highest increments flesh percentage values were recorded with ascorbic acid at $1000 \mathrm{ppm}$ followed by ascorbic acid at $750 \mathrm{ppm}$, ascorbic acid at $500 \mathrm{ppm}$ and control treatments, respectively in the two seasons.

The interaction effect of irrigation and spray treatment proved that the highest flesh percentage values were scored with irrigation level at $100 \%$ plus ascorbic acid at $1000 \mathrm{ppm}$, however, the lowest values were recorded with irrigation level at $60 \%$ with control treatment.

Table 8:- Effect of sustained deficit irrigation and foliar application of ascorbic acid on flesh (\%) and weight of 100 grains $(\mathrm{g})$ of Wonderful pomegranate trees ( $2017 \& 2018$ seasons).

\begin{tabular}{|c|c|c|c|c|c|c|c|c|c|c|}
\hline & \multicolumn{10}{|c|}{ Flesh $(\%)$} \\
\hline & \multicolumn{5}{|l|}{2017} & \multicolumn{5}{|l|}{2018} \\
\hline & \multicolumn{5}{|c|}{ Ascorbic acid } & \multicolumn{5}{|c|}{ Ascorbic acid } \\
\hline Treatments & $0 \mathrm{ppm}$ & $\begin{array}{l}500 \\
\text { ppm }\end{array}$ & $\begin{array}{l}750 \\
\mathrm{ppm}\end{array}$ & $\begin{array}{l}1000 \\
\text { ppm }\end{array}$ & Mean & $0 \mathrm{ppm}$ & $\begin{array}{l}500 \\
\mathrm{ppm}\end{array}$ & $\begin{array}{l}750 \\
\mathrm{ppm}\end{array}$ & $\begin{array}{l}1000 \\
\mathrm{ppm}\end{array}$ & Mean \\
\hline Irrigation $100 \%$ & $44.64 \mathrm{ef}$ & $45.51 \mathrm{de}$ & $47.69 \mathrm{c}$ & $50.87 \mathrm{a}$ & $47.18 \mathrm{~A}$ & $45.22 \mathrm{i}$ & $47.70 \mathrm{de}$ & $48.60 \mathrm{~cd}$ & $50.97 \mathrm{a}$ & $48.12 \mathrm{~A}$ \\
\hline Irrigation $80 \%$ & $43.52 \mathrm{gh}$ & $44.39 \mathrm{fg}$ & $46.57 \mathrm{~d}$ & $49.75 b$ & $46.06 \mathrm{~B}$ & $44.10 \mathrm{j}$ & $46.58 \mathrm{fg}$ & $47.48 \mathrm{ef}$ & $49.85 \mathrm{~b}$ & $47.00 \mathrm{~B}$ \\
\hline Irrigation $60 \%$ & $42.40 \mathrm{i}$ & $43.27 \mathrm{hi}$ & $45.45 \mathrm{ef}$ & $48.63 \mathrm{c}$ & $44.94 \mathrm{C}$ & $42.98 \mathrm{k}$ & 45.46hi & $46.36 \mathrm{gh}$ & $48.73 \mathrm{c}$ & $45.88 \mathrm{C}$ \\
\hline \multirow[t]{4}{*}{ Mean } & $43.52 \mathrm{D}$ & $44.39 \mathrm{C}$ & 46.57B & $49.75 \mathrm{~A}$ & & 44.10D & $46.58 \mathrm{C}$ & $47.48 \mathrm{~B}$ & $49.85 \mathrm{~A}$ & \\
\hline & \multicolumn{10}{|c|}{ Weight of 100 grains $(\mathrm{g})$} \\
\hline & \multicolumn{5}{|l|}{2017} & \multicolumn{5}{|l|}{2018} \\
\hline & \multicolumn{5}{|c|}{ Ascorbic acid } & \multicolumn{5}{|c|}{ Ascorbic acid } \\
\hline Treatments & $0 \mathrm{ppm}$ & $\begin{array}{l}500 \\
\mathrm{ppm}\end{array}$ & $\begin{array}{l}750 \\
\mathrm{ppm}\end{array}$ & $\begin{array}{l}1000 \\
\mathrm{ppm}\end{array}$ & Mean & $0 \mathrm{ppm}$ & $\begin{array}{l}500 \\
\text { ppm }\end{array}$ & $\begin{array}{l}750 \\
\text { ppm }\end{array}$ & $\begin{array}{l}1000 \\
\mathrm{ppm}\end{array}$ & Mean \\
\hline Irrigation $100 \%$ & $36.00 \mathrm{e}$ & $39.00 \mathrm{~h}$ & $40.33 \mathrm{~b}$ & $43.00 \mathrm{a}$ & $39.58 \mathrm{~A}$ & $37.00 \mathrm{~d}$ & $40.00 \mathrm{c}$ & $42.66 \mathrm{~b}$ & $44.33 \mathrm{a}$ & $41.00 \mathrm{~A}$ \\
\hline Irrigation $80 \%$ & $31.00 \mathrm{c}$ & $34.00 \mathrm{f}$ & $35.33 \mathrm{e}$ & $38.00 \mathrm{~d}$ & $34.58 \mathrm{~B}$ & $32.00 \mathrm{f}$ & $35.00 \mathrm{e}$ & $37.66 \mathrm{~d}$ & $39.33 \mathrm{c}$ & $36.00 \mathrm{~B}$ \\
\hline Irrigation $60 \%$ & $26.00 \mathrm{j}$ & $29.00 \mathrm{i}$ & $30.33 \mathrm{~h}$ & $33.00 \mathrm{~g}$ & $29.58 \mathrm{C}$ & $27.00 \mathrm{~h}$ & $30.00 \mathrm{~g}$ & $32.66 \mathrm{f}$ & $34.33 \mathrm{e}$ & $31.00 \mathrm{C}$ \\
\hline Mean & $31.00 \mathrm{D}$ & $34.00 \mathrm{C}$ & $35.33 \mathrm{~B}$ & $38.00 \mathrm{~A}$ & & $32.00 \mathrm{D}$ & $35.00 \mathrm{C}$ & $37.67 \mathrm{~B}$ & $39.34 \mathrm{~A}$ & \\
\hline
\end{tabular}

Means followed by the same letter (s) within each row, column or interaction are not significantly different at $5 \%$ level.

\section{Weight of 100 grains (g)}

Table, 8 indicates that increasing irrigation level and ascorbic acid spraying rate treatments results in increasing weight of 100 grains in the both seasons.

Furthermore, irrigation level at $100 \%$ plus ascorbic acid at $1000 \mathrm{ppm}$ spraying treatment proved to be the most effective combination in this respect in two seasons.

\section{Juice volume / fruit $\left(\mathrm{cm}^{3}\right)$}

Table, 9 shows that juice volume per fruit was significantly affected by irrigation levels and spraying treatments. Irrigation level of $100 \%$ gave the highest juice volume per fruit followed by irrigation at $80 \%$ and $60 \%$ in both seasons.

Concerning ascorbic acid spraying treatments the highest juice volume per fruit was recorded with ascorbic acid at $1000 \mathrm{ppm}$ followed by ascorbic acid at $750 \mathrm{ppm}$, ascorbic acid at $500 \mathrm{ppm}$ and control treatments, respectively.

Irrigation level at $100 \%$ with ascorbic acid at $1000 \mathrm{ppm}$ spraying treatment proved to be the most effective interaction in increasing juice volume per fruit. On the contrary, irrigation level at $50 \%$ combined with tab water spraying treatment gave comparatively the lowest value in this concern. 
Table 9:- Effect of sustained deficit irrigation and foliar application of ascorbic acid on Juice volume/fruit $\left(\mathrm{cm}^{3}\right)$ and Peel thickness $(\mathrm{cm})$ of Wonderful pomegranate trees (2017 \& 2018 seasons).

\begin{tabular}{|l|l|l|l|l|l|l|l|l|l|}
\hline \multicolumn{8}{|l|}{ Juice volume/fruit $\left(\mathrm{cm}^{3}\right)$} \\
\hline \multicolumn{9}{|l|}{2017} \\
\hline \multicolumn{8}{|l|}{ Ascorbic acid } \\
\hline
\end{tabular}

Means followed by the same letter (s) within each row, column or interaction are not significantly different at $5 \%$ level.

\section{Peel thickness (cm)}

Data presented in Table, 9 shows that the highest increment in peel thickness values were recorded with irrigation level at $60 \%$ followed by irrigation level at $80 \%$ and irrigation level at $100 \%$, respectively.

Furthermore, the highest increments peel thickness values were recorded with ascorbic acid at $1000 \mathrm{ppm}$ followed by ascorbic acid at $750 \mathrm{ppm}$ as compared to control treatments in both seasons.

The interaction effect of irrigation and spray treatment proved that the highest peel thickness values were scored with irrigation at $60 \%$ plus ascorbic acid at $1000 \mathrm{ppm}$, whilst the lowest values were recorded with irrigation at $100 \%$ with control treatment.

\section{Fruit total sugars content}

Table, 10 illustrate that irrigation level at $60 \%$ resulted the highest total sugar value followed descending by $80 \%$ and $100 \%$ irrigation in the two seasons, respectively. However, significant differences were noticed between the tested sustained deficit irrigation levels.

Moreover, the highest total sugar was recorded with ascorbic acid at $1000 \mathrm{ppm}$ followed by ascorbic acid at 750 ppm, ascorbic acid at $500 \mathrm{ppm}$ and control spraying treatments, respectively.

Concerning the interaction between the tested irrigation levels, and spraying treatments, $60 \%$ irrigation level combined with ascorbic acid at $1000 \mathrm{ppm}$ spraying treatment proved to be the best interaction in this regard.

Fruit T.S.S. (\%)

Table, 10 shows that TSS significantly affected by irrigation and spraying treatments. Irrigation level of $60 \%$ gave the highest TSS followed by irrigation level at $80 \%$ and $100 \%$.

Concerning spraying treatments the highest TSS was recorded with ascorbic acid at1000 ppm treatment, while control treatment recorded the lowest values in this respect.

Irrigation level at $60 \%$ with ascorbic acid foliar application at $1000 \mathrm{ppm}$ proved to be the most effective interaction in increasing TSS. On the contrary, irrigation at $100 \%$ combined with control spraying treatment gave comparatively the lowest value in this concern. 
Table 10:- Effect of sustained deficit irrigation and foliar application of ascorbic acid on total sugar (\%) and T.S.S. (\%) of Wonderful pomegranate trees ( 2017 \& 2018 seasons).

\begin{tabular}{|c|c|c|c|c|c|c|c|c|c|c|}
\hline & \multicolumn{10}{|c|}{ Total sugar $(\%)$} \\
\hline & \multicolumn{5}{|l|}{2017} & \multicolumn{5}{|l|}{2018} \\
\hline & \multicolumn{5}{|c|}{ Ascorbic acid } & \multicolumn{5}{|c|}{ Ascorbic acid } \\
\hline Treatments & $0 \mathrm{ppm}$ & $\begin{array}{l}500 \\
\text { ppm }\end{array}$ & $\begin{array}{l}750 \\
\text { ppm }\end{array}$ & $\begin{array}{l}1000 \\
\mathrm{ppm}\end{array}$ & Mean & $0 \mathrm{ppm}$ & $\begin{array}{l}500 \\
\mathrm{ppm}\end{array}$ & $\begin{array}{l}750 \\
\mathrm{ppm}\end{array}$ & $\begin{array}{l}1000 \\
\text { ppm }\end{array}$ & Mean \\
\hline Irrigation $100 \%$ & $11.00 \mathrm{~h}$ & $12.03 \mathrm{e}$ & $12.40 \mathrm{~d}$ & $12.69 \mathrm{c}$ & $12.94 \mathrm{C}$ & $11.44 \mathrm{~d}$ & $11.93 \mathrm{e}$ & $12.34 \mathrm{c}$ & $12.57 \mathrm{c}$ & $12.98 \mathrm{C}$ \\
\hline Irrigation $80 \%$ & $11.01 \mathrm{~g}$ & $12.25 \mathrm{de}$ & $12.78 \mathrm{c}$ & $13.11 \mathrm{~b}$ & $12.30 \mathrm{~B}$ & $11.45 \mathrm{f}$ & $12.28 \mathrm{~d}$ & $12.72 \mathrm{c}$ & $12.99 \mathrm{~b}$ & $12.36 \mathrm{~B}$ \\
\hline Irrigation $60 \%$ & $11.36 \mathrm{f}$ & $12.71 \mathrm{c}$ & $13.17 \mathrm{~b}$ & $13.53 \mathrm{a}$ & $12.69 \mathrm{~A}$ & $11.80 \mathrm{e}$ & $12.63 \mathrm{c}$ & $13.01 \mathrm{~b}$ & $13.41 \mathrm{a}$ & $12.73 \mathrm{~A}$ \\
\hline \multirow[t]{4}{*}{ Mean } & $11.01 \mathrm{D}$ & $12.33 \mathrm{C}$ & $12.79 \mathrm{~B}$ & $13.12 \mathrm{~A}$ & & $11.65 \mathrm{D}$ & $12.28 \mathrm{C}$ & $12.72 \mathrm{~B}$ & $12.99 \mathrm{~A}$ & \\
\hline & \multicolumn{10}{|c|}{ T.S.S. (\%) } \\
\hline & \multirow{2}{*}{\multicolumn{5}{|c|}{$\begin{array}{l}2017 \\
\text { Ascorbic acid }\end{array}$}} & \multicolumn{5}{|l|}{2018} \\
\hline & & & & & & Ascorbi & acid & & & \\
\hline Treatments & $0 \mathrm{ppm}$ & $\begin{array}{l}500 \\
\text { ppm }\end{array}$ & $\begin{array}{l}750 \\
\text { ppm }\end{array}$ & $\begin{array}{l}1000 \\
\mathrm{ppm}\end{array}$ & Mean & $0 \mathrm{ppm}$ & $\begin{array}{l}500 \\
\mathrm{ppm}\end{array}$ & $\begin{array}{l}750 \\
\text { ppm }\end{array}$ & $\begin{array}{l}1000 \\
\text { ppm }\end{array}$ & Mean \\
\hline Irrigation $100 \%$ & $13.98 \mathrm{~h}$ & $15.52 \mathrm{~d}$ & $15.14 \mathrm{e}$ & $15.79 \mathrm{c}$ & $14.94 \mathrm{C}$ & $13.89 \mathrm{~g}$ & $14.76 \mathrm{e}$ & $15.12 \mathrm{~d}$ & $15.62 \mathrm{c}$ & $14.85 \mathrm{C}$ \\
\hline Irrigation $80 \%$ & $14.33 \mathrm{~g}$ & $15.21 \mathrm{e}$ & $14.68 \mathrm{f}$ & $16.21 \mathrm{~b}$ & $15.31 \mathrm{~B}$ & $14.24 \mathrm{f}$ & $15.11 \mathrm{~d}$ & $15.51 \mathrm{c}$ & $16.04 \mathrm{~b}$ & $15.22 \mathrm{~B}$ \\
\hline Irrigation $60 \%$ & $14.68 \mathrm{f}$ & $15.56 \mathrm{~d}$ & $15.90 \mathrm{c}$ & $16.62 \mathrm{a}$ & $15.69 \mathrm{~A}$ & $14.59 \mathrm{e}$ & $15.46 \mathrm{c}$ & $15.89 \mathrm{~b}$ & $16.46 \mathrm{a}$ & $15.60 \mathrm{~A}$ \\
\hline Mean & $14.33 \mathrm{D}$ & $15.21 \mathrm{C}$ & $15.52 \mathrm{~B}$ & $16.21 \mathrm{~A}$ & & $14.24 \mathrm{D}$ & $15.11 \mathrm{C}$ & $15.51 \mathrm{~B}$ & $16.04 \mathrm{~A}$ & \\
\hline
\end{tabular}

Means followed by the same letter (s) within each row, column or interaction are not significantly different at $5 \%$ level.

Fruit total acidity content $(\%)$

Table, 11 shows that $60 \%$ irrigation gave the highest acidity value followed by, irrigation level at $80 \%$ in descending order. Meanwhile, the lowest fruit acidity value was recorded with irrigation level at $100 \%$ in both seasons.

In addition, the highest acidity value was recorded with control followed by ascorbic acid at $500 \mathrm{ppm}$, ascorbic acid at $750 \mathrm{ppm}$ and ascorbic acid at $1000 \mathrm{ppm}$, respectively.

Meanwhile, the interaction between irrigation levels and spraying treatments shows that the combination between irrigation level at $60 \%$ and ascorbic acid at $1000 \mathrm{ppm}$ gave the lowest value in this concern.

Irrigation level at $60 \%$ with spray treatments control (tap water) proved to be effective interaction in increasing acidity followed descending by ascorbic acid foliar spray at $500 \mathrm{ppm}$, ascorbic acid foliar spray at $750 \mathrm{ppm}$ treatment and spray treatment ascorbic acid at $1000 \mathrm{ppm}$ in both two seasons, respectively in this respect. The same trend noticed with other levels irrigation $80 \%$ or $100 \%$.

\section{Fruit T.S.S. /acid ratio}

Table, 11 illustrates that significant differences were noticed between the tested regulated deficit irrigation levels. However, full irrigation treatment resulted in the lowest TSS/acidity value, while the ratio was increased by reducing irrigation levels at $80 \%$ and $60 \%$ in both seasons.

Moreover, the highest TSS/acidity was recorded with ascorbic acid at $1000 \mathrm{ppm}$ followed by ascorbic acid at 750 , ascorbic acid at $500 \mathrm{ppm}$ and control spraying treatments, respectively.

Concerning the interaction between the tested irrigation levels, and spraying treatments, $60 \%$ irrigation combined with ascorbic acid at 1000 ppm spraying treatment proved to be the best interaction in this regard.

Table11:- Effect of sustained deficit irrigation and foliar application of ascorbic acid on acidity (\%)and T.S.S./acid ratio of Wonderful pomegranate trees ( 2017 \& 2018 seasons).

\begin{tabular}{|l|l|l|l|l|l|l|l|l|l|}
\hline \multicolumn{9}{|l|}{ Acidity (\%) } \\
\hline
\end{tabular}




\begin{tabular}{|c|c|c|c|c|c|c|c|c|c|c|}
\hline & & $\mathrm{ppm}$ & $\mathrm{ppm}$ & $\mathrm{ppm}$ & & & $\mathrm{ppm}$ & $\mathrm{ppm}$ & $\mathrm{ppm}$ & \\
\hline Irrigation $100 \%$ & $1.57 \mathrm{c}$ & $1.28 \mathrm{f}$ & $1.20 \mathrm{~g}$ & $1.01 \mathrm{i}$ & $1.26 \mathrm{C}$ & $1.63 \mathrm{c}$ & $1.41 \mathrm{f}$ & $1.24 \mathrm{~h}$ & $1.08 \mathrm{j}$ & $1.34 \mathrm{C}$ \\
\hline Irrigation $80 \%$ & $1.64 \mathrm{~b}$ & $1.36 \mathrm{e}$ & $1.29 \mathrm{f}$ & $1.10 \mathrm{~h}$ & $1.34 \mathrm{~B}$ & $1.70 \mathrm{~b}$ & $1.49 \mathrm{e}$ & $1.32 \mathrm{~g}$ & $1.17 \mathrm{i}$ & $1.42 \mathrm{~B}$ \\
\hline Irrigation $60 \%$ & $1.72 \mathrm{a}$ & $1.44 \mathrm{~d}$ & $1.36 \mathrm{e}$ & $1.19 \mathrm{~g}$ & $1.42 \mathrm{~A}$ & $1.77 \mathrm{a}$ & $1.56 \mathrm{~d}$ & $1.40 \mathrm{f}$ & $1.26 \mathrm{~h}$ & $1.50 \mathrm{~A}$ \\
\hline \multirow[t]{4}{*}{ Mean } & $1.64 \mathrm{~A}$ & $1.36 \mathrm{~B}$ & $1.28 \mathrm{C}$ & $1.10 \mathrm{D}$ & & $1.70 \mathrm{~A}$ & $1.49 \mathrm{~B}$ & $1.32 \mathrm{C}$ & $1.17 \mathrm{D}$ & \\
\hline & \multicolumn{10}{|c|}{ T.S.S./acid ratio } \\
\hline & \multicolumn{5}{|l|}{2017} & \multicolumn{5}{|l|}{2018} \\
\hline & \multicolumn{5}{|c|}{ Ascorbic acid } & \multicolumn{5}{|c|}{ Ascorbic acid } \\
\hline Treatments & $0 \mathrm{ppm}$ & $\begin{array}{l}500 \\
\text { ppm }\end{array}$ & $\begin{array}{l}750 \\
\text { ppm }\end{array}$ & $\begin{array}{l}1000 \\
\text { ppm }\end{array}$ & Mean & $0 \mathrm{ppm}$ & $\begin{array}{l}500 \\
\text { ppm }\end{array}$ & $\begin{array}{l}750 \\
\text { ppm }\end{array}$ & $\begin{array}{l}1000 \\
\mathrm{ppm}\end{array}$ & Mean \\
\hline Irrigation $100 \%$ & 8.351 & $10.74 \mathrm{i}$ & $11.77 \mathrm{f}$ & $14.20 \mathrm{c}$ & $11.26 \mathrm{C}$ & $8.11 \mathrm{k}$ & $9.89 \mathrm{i}$ & $11.38 \mathrm{f}$ & $13.39 \mathrm{c}$ & $10.69 \mathrm{C}$ \\
\hline Irrigation $80 \%$ & $8.65 \mathrm{k}$ & $11.06 \mathrm{~h}$ & $12.12 \mathrm{e}$ & $14.58 \mathrm{~b}$ & $11.60 \mathrm{~B}$ & $8.41 \mathrm{jk}$ & $10.21 \mathrm{~h}$ & $11.73 \mathrm{e}$ & $13.78 \mathrm{~b}$ & $11.03 \mathrm{~B}$ \\
\hline Irrigation $60 \%$ & $8.95 \mathrm{j}$ & $11.37 \mathrm{~g}$ & $12.47 \mathrm{~d}$ & $14.97 \mathrm{a}$ & $11.94 \mathrm{~A}$ & $8.71 \mathrm{j}$ & $10.53 \mathrm{~g}$ & $12.08 \mathrm{~d}$ & $14.16 \mathrm{a}$ & $11.37 \mathrm{~A}$ \\
\hline Mean & $8.65 \mathrm{D}$ & $11.06 \mathrm{C}$ & $12.12 \mathrm{~B}$ & $14.58 \mathrm{~A}$ & & $8.41 \mathrm{~d}$ & $10.21 \mathrm{c}$ & $11.73 \mathrm{~b}$ & $13.78 \mathrm{a}$ & \\
\hline
\end{tabular}

Means followed by the same letter (s) within each row, column or interaction are not significantly different at $5 \%$ level.

\section{Fruit ascorbic acid content}

Table, 12 shows that irrigation level at $60 \%$ give the highest ascorbic acid value followed by irrigation at $80 \%$. Meanwhile, the lowest ascorbic acid value was recorded with $100 \%$ irrigation level. In the first season no significantly between $100 \%$ and $80 \%$ irrigation levels.

In addition, the highest ascorbic acid value was recorded with foliar application of ascorbic acid at $1000 \mathrm{ppm}$ followed by ascorbic acid at 750 , ascorbic acid at $500 \mathrm{ppm}$, and control treatment which recorded the lowest values in this respect.

The combined effects of irrigation levels with spraying treatments showed that irrigation level at $60 \%$ with ascorbic acid at $1000 \mathrm{ppm}$ treatment were the most effective treatment in increasing ascorbic acid content of juice. Finally, the corresponding ones of $100 \%$ irrigation level combined with tab water foliar spray gave the less content of ascorbic acid in juice.

The enhancement effect of irrigation on fruit quality may be attributed that irrigation affected of the most physiological parameters and photosynthesis of olive trees (Masmoudi-Charfi et al., 2010) this led to effect in vegetative growth, yield and productive performance. The obtained results regarding the effect of deficit irrigation on fruit quality go in line with the findings of Abd-Ella (2011) found that the highest irrigation level enhanced fruit quality (fruit weight, diameter, length, TSS and V.C. of pomegranate fruits). Haneef et al. (2014) mentioned that application of irrigation level (100\%) registered maximum fruit weight, juice content, TSS : acid ratio of pomegranate fruits. Moreover, higher level of water stress (ETc 50) increased the TSS and decreased the vitamin C in comparison with water irrigation ETc 75 and full irrigation strategies of pomegranate (Parvizi and Sepaskhah 2015). Abdel-Sattar and Mohamed (2017) showed that TSS, TSS/ acidity, and vitamin C were the maximum values at $50 \%$ field capacity, while the acidity value was the highest in the treatment of $100 \%$ field capacity and yield the highest values of with the treatment of $100 \%$ field capacity of pomegranate trees.

The enhancement effect of ascorbic acid on fruit quality may be attributed that firstly, ascorbic acid increased leaf area and leaf chlorophyll content (Azzedine, et al., 2011). That is lead to enhancement photosynthesis process (Tarrafet et al., 1999).which reflected in more carbohydrate production and consequently improved fruit quality. Secondly, ascorbic acid increased IAA content which stimulates cell division as well as cell enlargement (Hassanein et al. 2009 and Abd-El Hamid 2009). Furthermore, auxin was increased fruit quality (Ragab, 2002). Thirdly, ascorbic acid mitigates the adverse effect on plant growth by enhanced proline accumulation (Azzedine, et al., 1997). The proposed function of the accumulated proline is osmosis regulation which has an adaptive mechanism to environmental stress (Aspinall and Paleg 1981). So that the increase in proline leads to enhancement leaf chlorophyll content and that reflected in more carbohydrate production through photosynthesis process and consequently improved fruit quality. The obtained results regarding the effect of ascorbic on fruit quality go in line with the findings of Atef (2018) on pomegranate. He mentioned that foliar sprays of ascorbic improved fruit quality of pomegranate fruit. Also, enhanced fruit quality of pomegranate trees (Fayed 2010 \& Ahmed et al., 2014). 
Table12:- Effect of sustained deficit irrigation and foliar application of ascorbic acid on ascorbic acid (mg/100 ml juice) and Water used efficiency (Kg.m ${ }^{-3}$.tree ${ }^{-1}$ ) of Wonderful pomegranate trees (2017 \& 2018 seasons).

\begin{tabular}{|c|c|c|c|c|c|c|c|c|c|c|}
\hline & \multicolumn{10}{|c|}{ Ascorbic acid (mg/100 ml juice) } \\
\hline & \multicolumn{5}{|c|}{2017} & \multicolumn{5}{|l|}{2018} \\
\hline & \multicolumn{5}{|c|}{ Ascorbic acid } & \multicolumn{5}{|c|}{ Ascorbic acid } \\
\hline Treatments & $0 \mathrm{ppm}$ & $\begin{array}{l}500 \\
\text { ppm }\end{array}$ & $\begin{array}{l}750 \\
\text { ppm }\end{array}$ & $\begin{array}{l}1000 \\
\text { ppm }\end{array}$ & Mean & $0 \mathrm{ppm}$ & $\begin{array}{l}500 \\
\text { ppm }\end{array}$ & $\begin{array}{l}750 \\
\text { ppm }\end{array}$ & $\begin{array}{l}1000 \\
\text { ppm }\end{array}$ & Mean \\
\hline Irrigation $100 \%$ & $13.64 \mathrm{k}$ & $14.54 \mathrm{~h}$ & $15.01 \mathrm{fg}$ & $16.13 \mathrm{c}$ & $14.83 \mathrm{~B}$ & $13.84 \mathrm{~d}$ & $14.70 \mathrm{~g}$ & $15.50 \mathrm{e}$ & $16.03 \mathrm{~cd}$ & $15.02 \mathrm{C}$ \\
\hline Irrigation $80 \%$ & $13.94 \mathrm{j}$ & $14.85 \mathrm{~g}$ & $15.36 \mathrm{e}$ & $16.51 \mathrm{~b}$ & $15.16 \mathrm{~B}$ & $14.14 \mathrm{~h}$ & $15.01 \mathrm{f}$ & $15.85 \mathrm{~d}$ & $16.42 b$ & $15.3 \mathrm{~B}$ \\
\hline Irrigation $60 \%$ & $14.24 \mathrm{i}$ & $15.17 \mathrm{ef}$ & $15.71 \mathrm{~d}$ & $16.89 \mathrm{a}$ & $15.50 \mathrm{~A}$ & $14.44 \mathrm{~g}$ & $15.33 \mathrm{e}$ & $16.20 \mathrm{c}$ & $16.80 \mathrm{a}$ & $15.69 \mathrm{~A}$ \\
\hline \multirow[t]{4}{*}{ Mean } & 13.94D & $14.85 \mathrm{C}$ & $15.36 \mathrm{~B}$ & $16.51 \mathrm{~A}$ & & $14.14 \mathrm{D}$ & $15.01 \mathrm{C}$ & $15.8 \mathrm{~B}$ & $16.42 \mathrm{~A}$ & \\
\hline & \multicolumn{10}{|c|}{ Water used efficiency $\left(\mathrm{Kg} \cdot \mathrm{m}^{-3} \cdot\right.$ tree $\left.^{-1}\right)$} \\
\hline & 2017 & & & & & 2018 & & & & \\
\hline & \multicolumn{5}{|c|}{ Ascorbic acid } & \multicolumn{5}{|c|}{ Ascorbic acid } \\
\hline Treatments & $0 \mathrm{ppm}$ & $\begin{array}{l}500 \\
\mathrm{ppm}\end{array}$ & $\begin{array}{l}750 \\
\mathrm{ppm}\end{array}$ & $\begin{array}{l}1000 \\
\text { ppm }\end{array}$ & Mean & $0 \mathrm{ppm}$ & $\begin{array}{l}500 \\
\text { ppm }\end{array}$ & $\begin{array}{l}750 \\
\text { ppm }\end{array}$ & $\begin{array}{l}1000 \\
\text { ppm }\end{array}$ & Mean \\
\hline Irrigation $100 \%$ & $0.09 \mathrm{~g}$ & $0.11 \mathrm{ef}$ & $0.12 \mathrm{de}$ & $014 \mathrm{~cd}$ & $0.11 \mathrm{C}$ & $0.09 \mathrm{~h}$ & $0.11 \mathrm{fg}$ & $0.13 \mathrm{de}$ & $0.14 \mathrm{c}$ & $0.12 \mathrm{C}$ \\
\hline Irrigation $80 \%$ & $0.10 \mathrm{fg}$ & $0.12 \mathrm{de}$ & $0.13 \mathrm{~cd}$ & $0.15 \mathrm{bc}$ & $0.13 \mathrm{~B}$ & $0.10 \mathrm{gh}$ & $0.12 \mathrm{ef}$ & $0.14 \mathrm{c}$ & $0.16 \mathrm{~b}$ & $0.13 \mathrm{~B}$ \\
\hline Irrigation $60 \%$ & $0.11 \mathrm{e}$ & $0.14 \mathrm{bc}$ & $0.15 \mathrm{~b}$ & $0.17 \mathrm{a}$ & $0.15 \mathrm{~A}$ & $0.12 \mathrm{ef}$ & $0.14 \mathrm{~cd}$ & $0.16 \mathrm{~b}$ & $0.18 \mathrm{a}$ & $0.15 \mathrm{~A}$ \\
\hline Mean & $0.10 \mathrm{D}$ & $0.13 \mathrm{C}$ & $0.14 \mathrm{~B}$ & $0.15 \mathrm{~A}$ & & $0.10 \mathrm{D}$ & $0.12 \mathrm{C}$ & $0.14 \mathrm{~B}$ & $0.16 \mathrm{~A}$ & \\
\hline
\end{tabular}

Means followed by the same letter (s) within each row, column or interaction are not significantly different at $5 \%$ level.

\section{Water use efficiency $\left(\mathrm{kg} / \mathrm{m}^{3}\right)$}

Table, 12 demonstrates that irrigation at $60 \%$ produced higher positive effect on water used efficiency followed by irrigation $80 \%$ and finally by the corresponding ones received irrigation at $100 \%$.

Furthermore, significant differences were found between spraying treatments in the two seasons, the highest increments flesh percentage values were recorded with ascorbic acid at $1000 \mathrm{ppm}$ followed by ascorbic acid at 750 ppm, ascorbic acid at $500 \mathrm{ppm}$ and control treatments in the two seasons.

Finally, the interaction between the two tested factors showed that treatment $100 \%$ irrigation combined with ascorbic acid $1000 \mathrm{ppm}$ spraying treatment proved to be the best interaction in this regard.

The obtained results regarding the effect of deficit irrigation on fruit quality go in line with the findings of Khattab et al. (2011) indicated that low irrigation level of $13 \mathrm{~m}^{3}$ /tree/year recorded the highest water use efficiency of pomegranate trees. Intrigliolo et al. (2012) showed that deficit irrigation caused increasing water use efficiency of pomegranate trees.

The obtained results regarding the effect of deficit irrigation on fruit quality go in line with the findings of Bakry et al. (2013) they mentioned that increasing foliar application levels of ascorbic acid significantly increased water use efficiency. And the interaction between the water irrigation requirements of $(80 \%$ irrigation $)$ and $(300 \mathrm{mg} / \mathrm{L})$ foliar application level of ascorbic acid gave the highest values of water use efficiency of wheat.

\section{Conclusion:-}

Sustained deficit irrigation is pronounce positive effect water used efficiency to saving water and protecting of water resources in the future, it is preferable to use the strategy of sustained irrigation deficit water in arid and semiarid areas. We can be reducing negative impacts sustained irrigation deficit by using spraying by ascorbic acid.

\section{Reference:-}

1. A.O.A.C., 1995. Association of Official Agricultural Chemists, Official Methods of Analysis, 15th ed. A.O.A.C., Washington, DC.

2. Abd-Ella E.K.E., 2011. Effect of Soil conditioners and Irrigation Levels on Growth and Productivity of Pomegranate Trees in the New Reclaimed Region. Alexandria Science Exchange Journal, vol.32, no.4,550-575. 
3. Abd-El-Hamid, E.K., 2009. Physiological effects of some phytoregulators on growth, productivity and yield of wheat plant cultivated in new reclaimed soil. PhD. Thesis, Girls College, Ain Shams Univ. Cairo, Egypt.

4. Abdel Latef A.A., 2010. Changes of antioxidative enzymes in salinity tolerance among different wheat cultivars. Cereal Res Commun 38:43-55.

5. Abd-El-Rhman I. E., Attia,M. F., Eman S. El-Hady, Laila, F. H., 2017. Effect of foliar spraying of some antioxidants and micronutrients on yield, fruit quality and leaf mineral content of Manfalouty pomegranate trees (Punica granatum L.) grown in a calcareous soil. Middle East J. Appl. Sci., 7(4): 713-725.

6. Abdel-Sattar, M. and . Mohamed, Y. I., 2017. Pomegranate Trees Productivity in Response to Three Levels of Irrigation and Slow or Fast Nitrogen Release Fertilizer as Well as their Combinations. J. Plant Production, Mansoura Univ., Vol. 8 (8): 813 - 820.

7. Abo - Taleb, A.S.; Noaman, F.V. and Sari El-Deen, S., 1998. Growth of pomegranate transplants as affected by different water regimes., Ann. Agric. Sci. Salinity Assessment and Management, 36: 1073- 1091.

8. Ahmed, F.F.; Akl, A.M.; Gobara, A.A. and Mansour, A.E., 1997. Yield and quality of Anna pple trees (Malusdomestica) in response to foliar application of ascorbine and citrine fertilizer. Egypt J. Hort., 25(2): 120139.

9. Ahmed, F.F.; Mohamed, M.M.; Abou El- Khashab, A.M.A. and Aeed, S.H.A., 2014. Controlling fruit splitting and improving productivity of Manfalouty pomegranate trees by using salicylic acid and some nutrients. World Rural Observations 6(1):87-93.

10. Allen, R. G.; Pereire, L. S.; Raes, D. and Smith, M., 1998. Crop evapotranspiration. Guide for computing crop water requirements. FAO Irrigation and Drain. 56.

11. Alscher, R.G., Donahne, J.L.and Cromer, C.L., 1997. Reactive oxygen species and antioxidants: relationships in green cells. Physiol. Plant, 100:224-233.

12. Andrews, P.K.; Johnson, J.R.; Fahy, D. and Gish, N., 1999. Sunburn protection in apples with ascorbic acid. Le Fruit Belge, 481: 157-161.

13. Aspinall, D.andPaleg, L.G., 1981. Proline accumulation: physiological aspects. In: Paleg, L.G., Aspinall, D. (Eds.), The Physiology and Biochemistry of Drought Resistance in Plants. Academic Press, Sydney, pp. 205241.

14. Atef, A., 2018. Managing crop production of pomegranate $\mathrm{cv}$. Wonderful via foliar application of ascorbic acid, proline and glycinbetaine under environmental stresses. International Journal of Environment 7(3): 95-103.

15. Azzedine, F.; Gherroucha, H. and Baka, M., 2011. Improvement of salt tolerance in durum wheat by ascorbic acid application. J. Stress Physiol. Biochem. 7: 27-37.

16. Bakry, A.B; Abdelraouf, R.E and Ahmed, 2013. Effect of drought stress and ascorbic acid foliar application on productivity and irrigation water use efficiency of wheat under newly reclaimed sandy soil. Elixir Agriculture 57A : 14398-14403

17. Barth, C.; Tullio, M.D. and Conklin, P.L., 2006. The role of ascorbic acid in the control of flowering time and the onset of senescence. J. Experimental Botany, 57(8): 1657-1665.

18. Chalmers, D.J.; Mitchell, P.D. and Van Heek, L., 1981. Control of peach tree growth and productivity by regulated water supply, tree density and summer pruning. J. Amer. Soc. Hort. Sci. 106, 307-312.

19. Conklin P. and Barth, C., 2004. Ascorbic acid, a familiar small molecule intertwined in the response of plants to ozone, pathogens, and the onset of senescence. Plant Cell Environ 27:959-970.

20. Davey M.; Montagu, M.; Inze, D.; Sanmartin, M.; Kanellis, A.; Smirnoff, N.; Benzie, I.; Strain, J.; Favell, D. and Fletcher, J., 2000. Plant L-ascorbic acid: chemistry, function, metabolism, bioavailability and effects of processing. J Sci Food Agric 80:825-860.

21. Doorembos, J. and Pruitt,W.O., 1977. Crop water requirements. FAO Irrigation and drainage paper No. 24 Food and Agriculture Organnnization of the Nations, Roma.

22. Duncan, D.B., 1955. Multiple range and multiple F test. Biometrics, 11: 1-24.

23. Elade, Y., 1992. The use of antioxidants to control gray mould (Botryticcibera) and white mould (SclerotiniaAclerotiorum) in various crops, Plant Pathol., 141: 417-426.

24. El-Masry, S.E.M., 1995. Physiological Studies to Control Pomegranate Fruit Disorders. M.Sc. Thesis Faculty of Agric., Assiut Univ., Egypt.

25. El-Sayed, O.M. ; El-Gammal, O.H.M. and Salama, A.S.M., 2014. Effect of ascorbic acid, proline and jasmonic acid foliar spraying on fruit set and yield of Manzanillo olive trees under salt stress. ScientiaHorticulturae, 176:32-37.

26. English M.J.; Musick, J.T. and Murty, V.V.N., 1990. Deficit irrigation. Journal of Farm Irrigation Systems. ASAE, 12 - 222-230. 
27. Fayed, T. A., 2010. Effect of compost tea and some antioxidant application on leaf chemical constituents, yield and fruit quality of pomegranate. World Jouranl of Agricultural Sciences 6 (4):402-411.

28. Fereres, E., and Soriano, M. A., 2007. Deficit irrigation for reducing agricultural water use. Journal of Experimental Botany, Vol. 58, No. 2, pp. 147-159.

29. Fereres, E.; Goldhamer, D.A. and Parsons, L.R.., 2003. Irrigation water management of horticultural crops. Hortscience 38, 1036-1042.

30. Ghanbarpour, E.; Mehdi R., Shaneka, L., 2018. Reduction of cracking in pomegranate fruit after foliar application of humic acid, calcium-boron and kaolin during water stress. Springer-Verlag GmbH Deutschland, einTeil von Springer Nature. https://doi.org/10.1007/s10341-018-0386-6.

31. Haneef, M; Kaushik, R.A.; Sarolia, D.K.; Mordia, A. and Mahesh D., 2014 Irrigation scheduling and fertigation in pomegranate cv. Bhagwa under high density planting system Indian J. Hort. 71(1), March 2014: 45-48.

32. Hassanein, R.A.; Bassony, F.M.; Barakat, D.M. and Khalil, R.R.., 2009. Physiological effects of nicotinamide and ascorbic acid on Zea mays plant grown under salinity stress. 1- Changes in growth, some relevant metabolic activities and oxidative defence systems. Res J AgricBiol Sci., 5:72-81.

33. Intrigliolo D.S.; García J.; Lozoya A.; Bonet L.; Nicolás E.; Alarcón J.J. and Bartual, J., 2012. Regulated deficit irrigation in pomegranate (Punica granatum) trees. Yield and its components. In :Melgarejo P. (ed.), Valero D. (ed.). II International Symposium on the Pomegranate. Zaragoza : CIHEAM / Universidad Miguel Hernández. p. 101-106 (Options Méditerranéennes :Série A. SéminairesMéditerranéens; n. 103).

34. Intrigliolo, D. S.; Nicolas, E.; Bonet, L.; Ferrer, P.; Alarcón, J. J. and Bartual, J., 2011. Water relations of feld grown pomegranate trees (Punica granatum) under different drip irrigation regimes. Agric. Water Manage. 98(4): 691-696.

35. Khan, M., 2006. Effect of sea salt and 1-ascorbic acid on the seed germination of halophytes. J. Arid Environ. 67:535-540.

36. Khattab M.; Ayman, M.; Shaban, E.; El-Shrief, A. H. and Mohamed, A. S. E., 2011. Growth and Productivity of Pomegranate Trees under Different Irrigation Levels I: Vegetative Growth and Fruiting. Journal of Horticultural Science \& Ornamental Plants 3 (2): 194-198.

37. Lee S.K. and Kader, A.A., 2000. Preharvest and postharvest factors influencing vitamin $\mathrm{C}$ content of horticultural crops. Post Harv. Biol. Technol. 20:207-220.

38. Nicholas, S., 1996. The function and metabolism of ascorbic acid in plants, Annals of Botany, 78:661-669.

39. Parvizi, H. and Sepaskhah, A.R., 2015. Effect of drip irrigation and fertilizer regimes on fruit quality of a pomegranate (Punica granatum (L.) cv. Rabab) orchard. Agricultural Water Management 156: 70-78.

40. Pattangul W. and Madore, M.A., 1999. Water deficit on raffinose family oligosaccharide metabolism in Coleus. Plant Physiology, 121: 987- 993.

41. Pereira L. S.; Theib, O. and Abdelaziz, Z., 2002. Irrigation management under water scarcity. Agricultural Water Management 57:175-206.

42. Pignocchi C. and Foyer, C.H., 2003. Apoplasticascorbate metabolism and its role in the regulation of cell signalling. CurrOpin Plant Biol 6: 379-389.

43. Ragab, M. M., 2002. Effect of spraying urea, ascorbic acid and NAA on fruiting of Washington Navel orange trees. M. Sc. Thesis. Fac. Agric. Minia. Univ. Egypt, Nutr. 16:163-166.

44. Shalata, A., and Peter, M. N., 2001: Exogenous ascorbic acid (vitamin C) increases resistance to salt stress and reduces lipid peroxidation. J. Exp. Bot. 52, 2207-2211.

45. Smirnoff, N., 1996. Botanical briefing: the function and metabolism of ascorbic acid in plants. Ann. Bot. 78 (6), 661-669.

46. Tarraf, S. A., Gamal El-Din, K.M. and Balbaa, L. K., 1999. The response of vegetative growth and essential oil of lemongrass (Cymbopogon citratesHort) to foliar application of ascorbic acid, nicotinamid and some micronutrients. Arab Univ. of Agric. Sci., 7: 247-259.

47. Tavousi , M.; Freidoon, K.; Amin, A.; Hossein, B. and Ali, T., 2015. Effects of Drought and Salinity on Yield and Water Use Efficiency in Pomegranate Tree. J. Mater. Environ. Sci. 6 (7) 1975-1980.

48. Westwood, M. N., 1993. Temperate-zone pomology. Physiology and culture, $3^{\text {rd }}$ ed. Timber press Inc., Portland, Oregon.

49. Yaron, B; Shalhevet, J.andShimishi, D., 1973. Patterns of salt distribution under trickle irrigation. Ecological Studies; Analysis and Syntheses. Vol. 4, Springer Verlay, Berlin, pp: 389-394.

50. Zahedi H and Tohidi M.,H.R., 2011. Effect of drought stress on antioxidant enzymes activities with zeolite and selenium application in canola cultivars. Res on crops 12 (2): 388-392.

51. Zhu, J. K., 2000: Genetic analysis of plant salt tolerance using arabidopsis. Plant Physiol. 124, 941- 948. 